\title{
Gastric floating matrix tablets: Design and optimization using combination of polymers
}

\author{
SHAILESH T. PRAJAPATI ${ }^{1 *}$ \\ LAXMANBHAI D. PATEL ${ }^{2}$ \\ DASHARATH M. PATEL \\ ${ }^{1}$ Department of Pharmaceutics \\ Shri Sarvajanik Pharmacy College \\ Mehsana-384001, Gujarat, India \\ ${ }^{2}$ Department of Pharmaceutics \\ DDIT Pharmacy College, Nadiad-387001 \\ Gujarat, India
}

Accepted April 3, 2008

\begin{abstract}
The purpose of the present study was to develop an optimized gastric floating drug delivery system (GFDDS) containing domperidone as a model drug. Box-Behnken design was employed in formulating the GFDDS with three polymers: hydroxypropyl methylcellulose K4M (HPMC K4M) $\left(\mathrm{X}_{1}\right)$, Carbopol 934P $\left(\mathrm{X}_{2}\right)$ and sodium alginate $\left(X_{3}\right)$, as independent variables. Floating lag time (FLT), total floating time (TFT), time required to release $50 \%$ of the drug $\left(t_{50}\right)$ and diffusion exponent $(n)$ were selected as dependent variables. Seventeen formulations were prepared, dissolution data obtained was fitted to the power law and floating profiles were analyzed. HPMC loading was found to be significant for floating properties. Carbopol loading had a negative effect on floating properties but was found helpful in controlling the release rate of the drug. No significant effect of sodium alginate on floating properties was observed but it was important for gel formation. The quadratic mathematical model developed could be used to predict formulations with desired release and floating properties.

Keywords: domperidone, floating matrix tablet, Box-Behnken design, GFDDS, release kinetics
\end{abstract}

The real challenge in the development of a controlled drug delivery system is not just to sustain the drug release but also to prolong the presence of the dosage form in the stomach or the upper small intestine until all the drug is completely released in the desired period of time (1-2). The residence of a drug delivery system in the upper part of the gastrointestinal tract (GIT) can be accomplished by several drug delivery systems, such as intragastric floating systems (3), swelling and expandable systems (4), bioadhesive systems (5), modified shape systems (6), high density systems (7), delayed gastric emptying systems (8) and low density super porous systems (9).

Domperidone is a synthetic benzimidazole compound that acts as a dopamine D2 receptor antagonist. Domperidone is also used as a prokinetic agent for treatment of up-

*Correspondence, e-mail address: stprajapati@gmail.com 
per gastrointestinal motility disorders (10). It continues to be an attractive alternative to metoclopramide because it has fewer neurological side effects. Patients receiving domperidone or other prokinetic agents for diabetic gastropathy or gastroparesis should be also managing a diet, lifestyle, and other medications to optimize gastric motility (11). After oral administration, domperidone is rapidly absorbed from the stomach and the upper part of the GIT with fewer side effects (12-14). It is a weak base with good solubility in acidic $\mathrm{pH}$ but significantly reduced solubility in alkaline medium. Such a weak base, formulated as an oral controlled release dosage form is exposed to environments of increasing $\mathrm{pH}$ with subsequent precipitation of poorly soluble free base within the formulation that is no longer capable of being released from the formulation (15).

The present study involved the design of domperidone gastric floating matrix tablets by combining three polymers: HPMC K4M, Carbopol 934P and sodium alginate, and investigation of the combined effect of these polymers on the floating behavior and in vitro release pattern of the drug.

\section{EXPERIMENTAL}

\section{Materials}

Domperidone was obtained as a gift sample (Mann Pharmaceutical Ltd., India). Hydroxypropyl methylcellulose K4M (HPMC K4M) and Carbopol 934P were received as gift samples from the Torrent Research Center (India). Sodium alginate (SA), sodium bicarbonate and lactose were purchased from S.D. Fine Chemicals (India).

\section{Methods}

Formulation design. - DESIGN EXPERT 6.0.11 (STAT-EASE) demo version software was used for formulation design. The Box-Behnken design was used in the study. In this design, three factors were evaluated and experimental trials were performed in all 17 possible combinations. The amounts of HPMC K4M $\left(\mathrm{X}_{1}\right)$, Carbopol 934P $\left(\mathrm{X}_{2}\right)$ and SA $\left(\mathrm{X}_{3}\right)$ were selected as independent variables. The floating lag time (FLT), total floating time (TFT) and times required for $50 \%$ of drug release $\left(t_{50}\right)$ and diffusion exponent $(n)$ were selected as dependent variables. The experimental design with the corresponding formulations is outlined in Table I. The statistical model:

$$
\mathrm{Y}=b_{0}+b_{1} \mathrm{X}_{1}+b_{2} \mathrm{X}_{2}+b_{3} \mathrm{X}_{3}+b_{11} \mathrm{X}_{1} \mathrm{X}_{1}+b_{22} \mathrm{X}_{2} \mathrm{X}_{2}+b_{12} \mathrm{X}_{1} \mathrm{X}_{2}+b_{23} \mathrm{X}_{2} \mathrm{X}_{3}+b_{13} \mathrm{X}_{1} \mathrm{X}_{3}+\mathrm{E}
$$

incorporating interactive and polynomial terms was used to evaluate the responses, where $Y$ is the dependent variable, $b_{0}$ is the mean response of 17 runs and $b_{i}$ is the estimated coefficient for factor $X_{i}$. The main effects $\left(X_{1}, X_{2}\right.$ and $\left.X_{3}\right)$ represent the average result of changing 1 factor at a time from its low to high values. The interaction terms $\left(X_{1} X_{2}, X_{2} X_{3}\right.$ and $\left.X_{1} X_{3}\right)$ show how the response changes when 2 factors are simultaneously changed. The polynomial terms $\left(X_{1} X_{1}, X_{2} X_{2}\right.$, and $\left.X_{3} X_{3}\right)$ are included to investigate nonlinearity. 
S. T. Prajapati et al.: Gastric floating matrix tablets: Design and optimization using combination of polymers, Acta Pharm. 58 (2008) 221-229.

Fabrication of domperidone floating tablets. - Domperidone was mixed with the required quantity of HPMC K4M, Carbopol 934P, SA, sodium bicarbonate and lactose with a spatula in a mortar for $5 \mathrm{~min}$. Isopropyl alcohol was added dropwise until a suitable mass for granulation was obtained. Then the wet mass was granulated through a sieve with $420 \mu \mathrm{m}$ aperture size. The granules were dried at room temperature $\left(35^{\circ} \mathrm{C}\right)$ for $1 \mathrm{~h}$ and then blended with 5\% polyethylene glycol 4000, 1\% magnesium stearate and compressed on a 10-station rotary tablet compression machine (Rimek, India) using a 8-mm standard flat-face punch. The prepared tablets were round and flat with an average diameter of $8.0 \pm 0.1 \mathrm{~mm}$ and a thickness of $2.8 \pm 0.2 \mathrm{~mm}$.

In vitro buoyancy studies. - The in vitro buoyancy was determined by floating lag times according to the method described by Rosa et al. (16). The tablets were placed in a $100-\mathrm{mL}$ beaker containing $0.1 \mathrm{~mol} \mathrm{~L}^{-1} \mathrm{HCl}$. The time required for the tablet to rise to the surface and float was taken as the floating lag time. The experiments were conducted in triplicate.

In vitro dissolution studies. - The release rate of domperidone from floating matrix tablets $(n=3)$ was determined according to British Pharmacopoeia (17) using the Dissolution Testing Apparatus 2 (paddle method). The dissolution test was performed using $900 \mathrm{~mL}$ of $0.1 \mathrm{~mol} \mathrm{~L}^{-1} \mathrm{HCl}$, at $37 \pm 0.5^{\circ} \mathrm{C}$ and $50 \mathrm{rpm}$. A $5-\mathrm{mL}$ sample was withdrawn from the dissolution apparatus hourly for $12 \mathrm{~h}$, and the samples were replaced with fresh dissolution medium. The samples were filtered through a $0.45-\mu \mathrm{m}$ membrane filter and diluted to a suitable concentration with $0.1 \mathrm{~mol} \mathrm{~L}^{-1} \mathrm{HCl}$. Absorbance of these solutions was measured at $284 \mathrm{~nm}$ using a Shimadzu UV-1700 UV/Vis double-beam spectrophotometer (Japan). Cumulative drug release was calculated using the equation generated from Beer Lambert's calibration curve in the linearity range of 0-25 $\mu \mathrm{g} \mathrm{mL}^{-1}$. FLT and TFT of the tablets were measured during dissolution studies. The $t_{50}$ and $n$ were calculated based on the Korsmeyer and Peppas model (18).

Statistical analysis. - Statistical analysis of the Box-Behnken design batches was performed by multiple regression analysis using Microsoft Excel. To evaluate the contribution of each factor with different levels to the response, the two-way analysis of variance (ANOVA) was performed using the DESIGN EXPERT 6.0.11 (STAT-EASE) demo version software. To graphically demonstrate the influence of each factor on the response, the response surface plots were generated using the DESIGN EXPERT 6.0.11 (STAT-EASE) demo version software.

\section{RESULTS AND DISCUSSION}

In the present investigation, combinations of three polymers were studied using the Box Behken design. The mathematical models developed for all the dependent variables using statistical analysis software are shown in Equations (1)-(4):

$$
\begin{gathered}
\text { FLT }=8.41+0.63 \mathrm{X}_{1}-2.13 \mathrm{X}_{2}+3.25 \mathrm{X}_{3}+3.51 \mathrm{X}_{1} \mathrm{X}_{2}+2.75 \mathrm{X}_{1} \mathrm{X}_{3}+ \\
+1.25 \mathrm{X}_{2} \mathrm{X}_{3}-5.95 \mathrm{X}_{1} \mathrm{X}_{1}+7.55 \mathrm{X}_{2} \mathrm{X}_{2}+3.32 \mathrm{X}_{3} \mathrm{X}_{3} \\
R=0.599582
\end{gathered}
$$




$$
\begin{gathered}
\text { TFT }=5.98+4.6875 \mathrm{X}_{1}-3.2625 \mathrm{X}_{2}-0.21 \mathrm{X}_{3}-4.47 \mathrm{X}_{1} \mathrm{X}_{2}- \\
-6.92 \mathrm{X}_{1} \mathrm{X}_{3}-2.35 \mathrm{X}_{2} \mathrm{X}_{3}+3.40 \mathrm{X}_{1} \mathrm{X}_{1}-0.65 \mathrm{X}_{2} \mathrm{X}_{2}+1.72 \mathrm{X}_{3} \mathrm{X}_{3} \\
R=0.898329 \\
t_{50}=14.84-0.14 \mathrm{X}_{1}-0.28 \mathrm{X}_{2}+1.21 \mathrm{X}_{3}-0.45 \mathrm{X}_{1} \mathrm{X}_{2}+1.08 \mathrm{X}_{1} \mathrm{X}_{3}- \\
-0.05 \mathrm{X}_{2} \mathrm{X}_{3}+1.7425 \mathrm{X}_{1} \mathrm{X}_{1}+1.87 \mathrm{X}_{2} \mathrm{X}_{2}-0.66 \mathrm{X}_{3} \mathrm{X}_{3} \\
R=0.928214 \\
n=0.38+0.02 \mathrm{X}_{1}-0.01 \mathrm{X}_{2}+0.02 \mathrm{X}_{3}-0.01 \mathrm{X}_{1} \mathrm{X}_{2}-0.03 \mathrm{X}_{1} \mathrm{X}_{3}- \\
-0.01 \mathrm{X}_{2} \mathrm{X}_{3}-0.07 \mathrm{X}_{1} \mathrm{X}_{1}+0.02 \mathrm{X}_{2} \mathrm{X}_{2}-0.04 \mathrm{X}_{3} \mathrm{X}_{3} \\
R=0.845881
\end{gathered}
$$

The floating lag time for all tablets was found to be below $33 \mathrm{~s}$ regardless of the content of polymers used (Table I), indicating insignificant effect of the concentration of po-

Table I. Formulation and dissolution characteristics (response data) of batches in the Box-Behnken design ${ }^{a}$

\begin{tabular}{lcccrrcc}
\hline Batch & $\mathrm{X}_{1}(\%)$ & $\mathrm{X}_{2}(\%)$ & $\mathrm{X}_{3}(\%)$ & \multicolumn{1}{c}{ FLT (s) } & TFT $(\mathrm{h})$ & \multicolumn{1}{c}{$t_{50}(\mathrm{~h})$} & $n$ \\
\hline B1 & 10 & 15 & 25 & $2 \pm 1$ & $2.5 \pm 0.4$ & $13.1 \pm 0.0$ & $0.48 \pm 0.02$ \\
B2 & 20 & 5 & 15 & $9 \pm 2$ & $10.0 \pm 0.4$ & $12.5 \pm 0.1$ & $0.57 \pm 0.01$ \\
B3 & 30 & 5 & 25 & $4 \pm 2$ & $24.0 \pm 0.3$ & $13.3 \pm 0.0$ & $0.52 \pm 0.03$ \\
B4 & 10 & 10 & 15 & $11 \pm 2$ & $4.2 \pm 0.3$ & $12.0 \pm 0.1$ & $0.60 \pm 0.02$ \\
B5 & 10 & 10 & 35 & $5 \pm 2$ & $5.3 \pm 0.3$ & $11.9 \pm 0.0$ & $0.65 \pm 0.07$ \\
B6 & 20 & 5 & 35 & $3 \pm 2$ & $24.0 \pm 0.3$ & $14.8 \pm 0.1$ & $0.52 \pm 0.01$ \\
B7 & 30 & 10 & 35 & $26 \pm 4$ & $5.6 \pm 0.4$ & $14.7 \pm 0.1$ & $0.51 \pm 0.01$ \\
B8 & 10 & 5 & 25 & $4 \pm 2$ & $8.0 \pm 0.4$ & $12.0 \pm 0.0$ & $0.39 \pm 0.02$ \\
B9 & 20 & 10 & 25 & $3 \pm 2$ & $2.5 \pm 0.2$ & $15.8 \pm 0.0$ & $0.44 \pm 0.01$ \\
B10 & 30 & 15 & 25 & $15 \pm 3$ & $4.4 \pm 0.1$ & $12.0 \pm 0.0$ & $0.52 \pm 0.03$ \\
B11 & 20 & 15 & 15 & $33 \pm 4$ & $3.6 \pm 0.3$ & $12.8 \pm 0.0$ & $0.62 \pm 0.02$ \\
B12 & 20 & 15 & 25 & $15 \pm 4$ & $4.9 \pm 0.2$ & $11.1 \pm 0.0$ & $0.47 \pm 0.04$ \\
B13 & 30 & 10 & 15 & $3 \pm 1$ & $24.0 \pm 0.4$ & $11.3 \pm 0.1$ & $0.36 \pm 0.06$ \\
B14 & 20 & 10 & 25 & $24 \pm 3$ & $4.8 \pm 0.2$ & $10.5 \pm 0.0$ & $0.50 \pm 0.01$ \\
B15 & 20 & 10 & 25 & $10 \pm 2$ & $6.8 \pm 0.5$ & $15.0 \pm 0.1$ & $0.48 \pm 0.04$ \\
B16 & 20 & 10 & 25 & $6 \pm 2$ & $7.0 \pm 0.4$ & $13.2 \pm 0.1$ & $0.70 \pm 0.03$ \\
B17 & 20 & 10 & 25 & $12 \pm 2$ & $4.2 \pm 0.3$ & $13.2 \pm 0.0$ & $0.45 \pm 0.02$ \\
\hline
\end{tabular}

${ }^{a} t_{50}$ - time requir ed to release $50 \%$ of drug, $X_{1}$ - amount of HPMC K4M, $X_{2}-$ amount of Carbopol 934P, $\mathrm{X}_{3}$ - amount of sodium alginate.

All batches contain $30 \mathrm{mg}$ of domperidone, 10\% sodium bicarbonate, $5 \%$ polyethylene glycol, $1 \%$ magnesium stearate, and a sufficient quantity of lactose to adjust the average mass of tablets to $180 \mathrm{mg}$. 

221-229.

lymers (Table II). Lower value of the correlation coefficient (Eq. 1) clearly indicates that the response is independent of the factors studied. This was due to evolution and entrapment of carbon dioxide inside the hydrated polymeric matrices, resulting from the interaction between the gas generating agent $\left(\mathrm{NaHCO}_{3}\right)$ and dissolution medium $(0.1$ mol L ${ }^{-1} \mathrm{HCl}, \mathrm{pH} 1.2$ ) which led to lowering of the density of matrices enabling the tablets to float.

The results of TFT and $t_{50}$ showed wide variations (Table I). From the results of multiple regression analysis, it was found that the dependent variables, TFT and $t_{50}$, are strongly dependent on the independent variables $(p<0.05$, Table II). The correlation coefficients indicate a good fit. Polynomial equations (Eq. 2 and 3) can be used to draw a conclusion after considering the magnitude of the coefficient and the mathematical sign it carries (positive or negative). As the amount of Carbopol 934P increased, TFT decreased; this may be due to high affinity of Carbopol toward water, which promotes water penetration into tablet matrices, leading to increased density. As the amount of HPMC K4M increased, TFT increased; this is because of increased gel strength of matrices, which prevents escape of evolved carbon dioxide from matrices, leading to decreased density. As the amount of SA increased, TFT decreased; this is because of the poor gelling strength of SA compared to HPMC K4M. This effect of polymer concentration is reflected in formulations B3, B6 and B13 (shown in Table I). As the amount of HPMC K4M

Table II. Analysis of variance for dependent variables from the Box Behnken design

\begin{tabular}{|c|c|c|c|c|c|}
\hline Source & SS & $\mathrm{df}$ & MS & F-value & Probability \\
\hline \multicolumn{6}{|l|}{ FLT } \\
\hline Regression & 209.25 & 6 & 34.875 & 0.416031 & 0.8524 \\
\hline Residual & 838.2794 & 10 & 83.82794 & & \\
\hline Total & 1047.529 & 16 & & & \\
\hline \multicolumn{6}{|l|}{ TFT } \\
\hline Regression & 225.4207 & 9 & 25.04674 & 9.179194 & 0.0040 \\
\hline Residual & 19.1005 & 7 & 2.728643 & & \\
\hline Total & 244.5212 & 16 & & & \\
\hline \multicolumn{6}{|l|}{$t_{50}$} \\
\hline Regression & 47.83579 & 9 & 5.315088 & 10.05693 & 0.0030 \\
\hline Residual & 3.6995 & 7 & 0.5285 & & \\
\hline Total & 51.53529 & 16 & & & \\
\hline \multicolumn{6}{|l|}{$n$} \\
\hline Regression & 0.03816 & 9 & 0.00424 & 1.418594 & 0.3297 \\
\hline Residual & 0.020922 & 7 & 0.002989 & & \\
\hline Total & 0.059081 & 16 & & & \\
\hline
\end{tabular}

SS - sum of squares

$\mathrm{df}$ - degrees of freedom

MS - mean of square

F - Fischer's ratio 
S. T. Prajapati et al:: Gastric floating matrix tablets: Design and optimization using combination of polymers, Acta Pharm. 58 (2008) 221-229.

a)

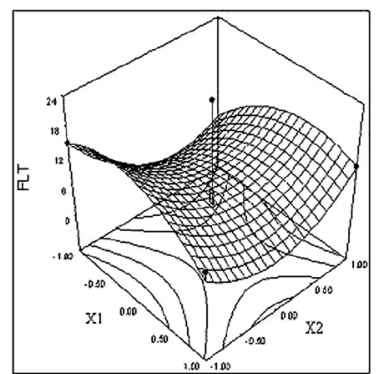

b)

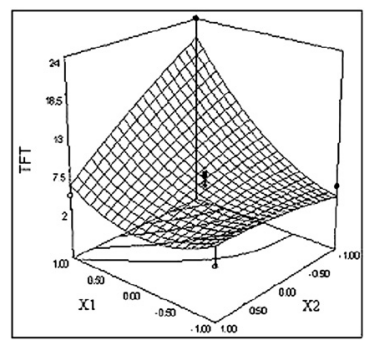

c)

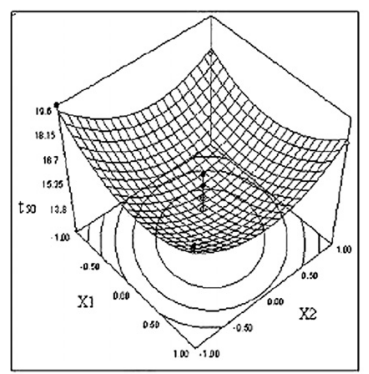

d)

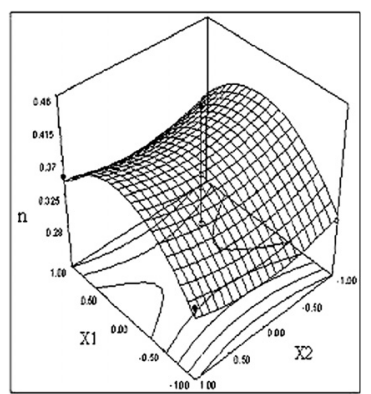

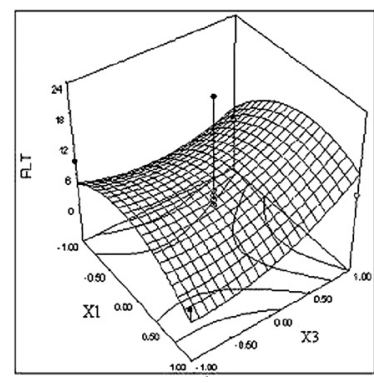
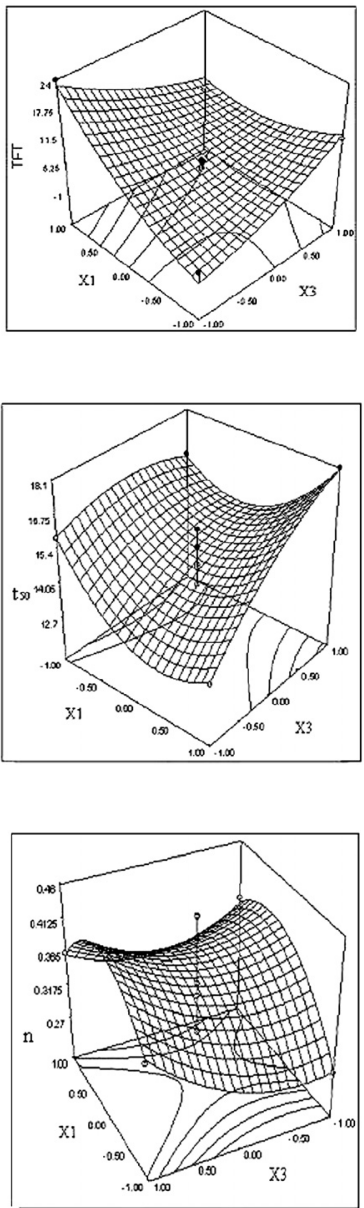

Fig. 1. Response surface plot for the effect of polymer amount on a) floating lag time (FLT); b) total floating time (TFT); c) time required for $50 \%$ drug release $\left(t_{50}\right)$; d) diffusion exponent $(n)$. X1 amount of HPMC K4M, X2 - amount of Carbopol 934P; X3 - amount of sodium alginate. 

221-229.

and Carbopol 934P increased, $t_{50}$ decreased; this may be due again to high affinity of HPMC and Carbopol toward water, which promotes water penetration into tablet matrices, leading to solubilization of domperidone. As the amount of SA increased, $t_{50}$ decreased; probably because of poor water affinity of SA compared to HPMC K4M and Carbopol 934P.

To demonstrate graphically the effect of the amount of HPMC K4M and Carbopol 934P and SA, the response surface plots were generated for the dependent variables FLT, TFT, $t_{50 \%}$ and $n$ (Fig. 1 ).

Dissolution profiles of the developed formulations are compared in Fig. 2. The dissolution profiles were fitted with the power law equation given by Korsmeyer and Pappas (18). Although the type of polymer and its concentration had significant influence on TFT and $t_{50}(p<0.05$, Table II), the diffusion exponent ranged from 0.386 to 0.695 , indicating anomalous drug release involving a combination of swelling, diffusion and/or erosion of matrices. This might be due to poor water solubility of domperidone as well as different characteristics of polymers. Nonlinear relationship was obtained between the diffusion exponent and three independent variables. It was observed that as the concentration of HPMC K4M increased, diffusion exponent increased up to an intermediate value and decreased. Carbopol 934P concentration had no significant effect on the value of $n$. As the concentration of SA increased, the values of $n$ decreased.

Fig. 2. Comparative release pro-

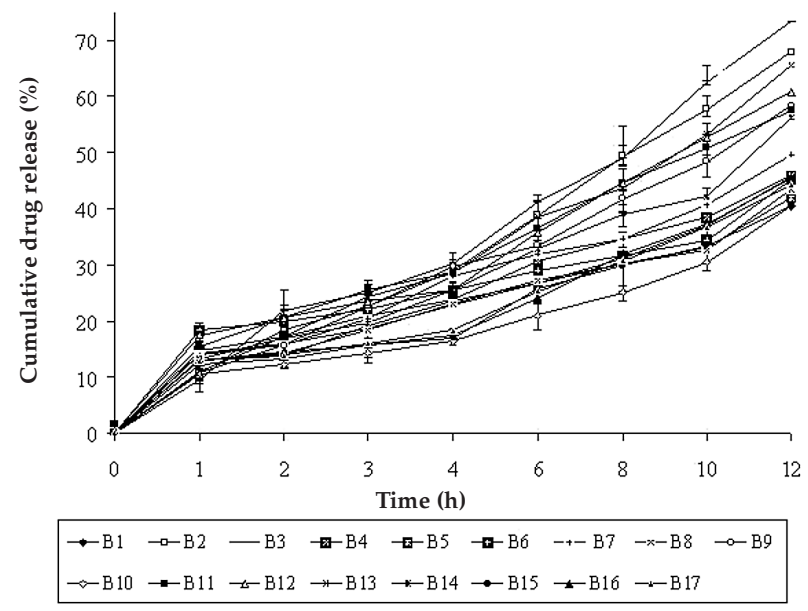

file of developed formulations.

\section{CONCLUSIONS}

HPMC K4M, Carbopol 934P and SA significantly affect TFT of the formulated GFDDS. When they are used in combination for developing GFDDS, high to moderate amount of HPMC K4M, low to moderate amount of Carbopol 934P and low to high 
amount of SA is to be used to achieve the desired TFT and release profile required for once daily formulations.

Acknowledgments. - Authors are thankful to Maan Pharmaceutical Pvt. Ltd (Mehsana, India) for providing gift sample of domperidone and Torrent research Center (Gandhinagar, India) for providing HPMC K4M and Carbopol 934P.

\section{REFERENCES}

1. A. A. Deshpande, C. T. Rhodes, N. H. Shah, A. W. Malick, Controlled-release drug delivery systems for prolonged gastric residence: an overview, Drug. Dev. Ind. Pharm. 22 (1996) 631-539; DOI: $10.3109 / 03639049609063217$.

2. S. J. Hwang, H. Park and K. Park, Gastric retentive drug-delivery systems, Crit. Rev. Ther. Drug. Carrier. Syst. 15 (1998) 243-283.

3. A. A. Deshpande, N. H. Shah, C. T. Rhodes and A. W. Malick. Development of a novel controlled-release system for gastric retention, Pharm. Res. 14 (1997) 815-819; DOI: 10.1023/A:1012171010492.

4. S. Li, S. Lin, Y. W. Chein, B. P. Daggy and H. L. Mirchandani, Statistical optimisation of gastric floating system for oral controlled delivery of calcium, AAPS Pharm. Sci. Tech. 2 (2001) article 1; http://www.pharmscitech.com.

5. S. Li, S. Lin, B. P. Daggy, H. L. Mirchandani and Y. W. Chein, Effect of HPMC and carbopol on the release and the floating properties of gastric floating drug delivery system using factorial design, Int. J. Pharm. 253 (2003) 13-22; DOI: 10.1016/S0378-5173(02)00642-7.

6. F. Kedzierewicz, P. Thouvenot, J. Lemut, A. Etienne, M. Hoffman and P. Maincent, Evaluation of peroral silicone dosage forms in humans by gamma-scintigraphy, J. Control. Rel. 58 (1999) 195-205; DOI: 10.1016/S0168-3659(98)00154-0.

7. S. S. Davis, A. F. Stockwell, M. J. Taylor, J. G. Hardy, D. R. Whalley, C. G. Wilson, H. Bechgaard and F. N. Christensen, The effect of density on the gastric emptying of single and multiple-unit dosage forms, Pharm. Res. 3 (1986) 208-213; DOI: 10.1023/A: 1016334629169.

8. R. Groning and G. Heun, Dosage forms with controlled gastrointestinal passage-studies on the absorption of nitrofurantoin, Int. J. Pharm. 56 (1989) 111-116; DOI: 10.1016/0378-5173(89)900033.

9. A. Streubel, J. Siepmann and R. Bodmeier, Floating matrix tablets based on low density foam powder: effects of formulation and processing parameters on drug release, Eur. J. Pharm. Sci. 18 (2003) 37-45; DOI: 10.1016/S0928-0987(02)00223-3.

10. Martindale - The Extra Pharmacopoeia, $31^{\text {st }}$ ed., Pharmaceutical Press, London 1996, pp. 1217-1218.

11. M. Albright Lisa, Use of domperidone as a prokinetic and antiemetic, health and wellness, Int. J. Pharm. Comp. 9 (2005) 120-125.

12. B. Mehta, P. Doshi, M. Joshi and M. Dattat, Floating Osmotic Device for Controlled Release Drug Delivery, U.S. Pat. 9,92,897 3 March 2003.

13. K. Naonori, H. Yatabe, K. Iseki and M. Katsumi, A new type of $\mathrm{pH}$ independent controlled release tablet, Int. J. Pharm. 68 (1991) 255-264; DOI: 10.1016/0378-5173(91)90147-G.

14. K. Thomma and T. Zimmer, Retardation of weakly basic drug with diffusion tablet, Int. J. Pharm. 58 (1990) 197-202; DOI: 10.1016/0378-5173(90)90195-A.

15. P. R. Sheth and J. L. Tossounian, Sustained Release Tablet Formulations, U.S. Pat. 4,140,755 2 Feb 1979. 
S. T. Prajapati et al.: Gastric floating matrix tablets: Design and optimization using combination of polymers, Acta Pharm. 58 (2008) 221-229.

16. M. Rosa, H. Zia and T. Rhodes, Dosing and testing in-vitro of a bioadhesive and floating drug delivery system for oral application. Int. J. Pharm. 105 (1994) 65-70; DOI: 10.1016/0378-5173(94) 90236-4.

17. British Pharmacopoeia, HMSO, London 2000, pp. 732.

18. N. A. Peppas, Analysis of Fickian and non-Fickian drug release from polymers, Pharm. Acta Helv. 60 (1985) 110-111.

\title{
$S A \check{Z} E T A K$
}

\section{Plutajuće matriks tablete: Dizajniranje i optimizacija kombiniranjem polimera}

\author{
SHAILESH T. PRAJAPATI, LAXMANBHAI D. PATEL i DASHARATH M. PATEL
}

Cilj rada bio je razvoj i optimizacija plutajućih sustava za isporuku lijekova u želucu (GFDDS) s domperidonom kao modelom lijeka. Box-Behnkenovo dizajniranje korišteno je $\mathrm{u}$ formuliranju GFDDS. Nezavisne varijable $\mathrm{u}$ dizajniranju bila su tri polimera: hidroksipropil metilceluloza K4M (HPMC K4M) $\left(\mathrm{X}_{1}\right)$, Carbopol 934P $\left(\mathrm{X}_{2}\right)$ i natrijev alginat $\left(\mathrm{X}_{3}\right)$, a zavisne varijable usporeno vrijeme plutanja (FLT), ukupno vrijeme plutanja (TFT), vrijeme potrebno za oslobađanje 50\% lijeka $\left(t_{50}\right)$ i difuzijski eksponent $(n)$. Pripravljeno je ukupno sedamnaest formulacija. Analizirani su podaci o oslobađanju ljekovite tvari. Količina HPMC značajno utječe na svojstva plutanja, dok količina karbopola ima negativni učinak na svojstvo plutanja, ali kontrolira oslobađanje ljekovite tvari. Natrijev alginat nema značajni učinak na svojstva plutanja, ali utječe na stvaranje gela. Kvadratni matematički model može se upotrijebiti za predviđanje formulacija sa željenim profilom oslobađanja i svojstvima plutanja.

Ključne riječi: domperidon, plutajuće matriks tablete, Box-Behnkenovo dizajniranje, GFDDS, kinetika oslobađanja

Department of Pharmaceutics, Shri Sarvajanik Pharmacy College, Mehsana-384001, Gujarat, India

Department of Pharmaceutics, DDIT Pharmacy College, Nadiad-387001, Gujarat, India 